\title{
ПСИХОЛОГІя
}

DOI https://doi.org/10.32405/2522-9931-2020-13(42)-10-38

УДК 316.4.06

\section{Бондаревська Ірина,}

кандидат психологічних наук, доцент,

Голова Правління ГО «Центр особистісних та соціальних трансформацій»,

доцент кафедри психології управління

Центрального інституту післядипломної освіти

ДЗВО «Університет менеджменту освіти»,

старший науковий співробітник лабораторії

психології масової комунікації та медіаосвіти

Інституту соціальної та політичної психології НАПН України.

Київ, Україна.

ORCID iD: https://orcid.org/0000-0002-7006-0979

SCOPUS ID: 57196437901

bondarevskaya@ua.fm

\author{
Михайленко Вікторія Олександрівна, \\ кандидат психологічних наук, доцент, \\ доцент кафедри суспільно-гуманітарної підготовки \\ Одеської державної академії технічного регулювання та якості. \\ Одеса, Україна. \\ ORCID iD: https://orcid.org/0000-0003-2584-5571 \\ mykhaylenkova@ukr.net
}

\section{НАВЧАЛЬНА ПРОГРАМА «ПСИХОЛОГІЯ ЕКОНОМІЧНОЇ ПОВЕДІНКИ ФАХІВЦЯ» 3 МЕТОДИКАМИ АРТРОЗВИТКУ}

\begin{abstract}
Анотація. У статті представлено зміст та структуру навчальної програми «Психологія економічної поведінки фахівця». Спецкурс містить комплекс методик артрозвитку як методик актуалізації потенціалу особистості фахівця в освіті дорослих. Спецкурс було розроблено та впроваджено на кафедрі психології управління Центрального інституту післядипломної освіти ДЗВО «Університет менеджменту освіти». У результаті опанування змісту даного спецкурсу фахівці отримають знання щодо особливостей довіри в економічних та міжетнічних стосунках; усвідомлять особливості функціонування соціального капіталу в різних спільнотах та роль громадянської активності в забезпеченні сталого економічного розвитку; зможуть розвинути вміння та навички попередження корупційної поведінки як такої, що підриває економічну довіру та
\end{abstract}


загрожує функціонуванню соціального капіталу. Методики артрозвитку через усвідомлення своїх почуттів, емоцій, станів допомагають фахівцям подивитися на зміни з точки зору перспектив розвитку, що відкриваються, доводять ресурсність постійного навчання. Коли навички доводиться постійно оновлювати, щоб залишатися конкурентоспроможними, психологічна готовність до постійного навчання у дорослому віці, не зважаючи на професійні досягнення, які $\epsilon$, за допомогою навичок, які вже застарілі, стає необхідною умовою для успішної професійної діяльності. Таку готовність до постійного навчання також можна розглядати як профілактику психологічних травм під час проходження професійних криз. Актуалізація, розвиток та реалізація потенціалу особистості часто відбуваються в процесі переходу з однієї професійної сфери в іншу. Орієнтація на свої цінності в невизначеному VUCA-світі потребує усвідомлення цих цінностей та цілей як орієнтира під час вибору стратегії поведінки і варіантів вчинків в кожній конкретній ситуації. Візуальна метафора розглядається як невід'ємний компонент освіти дорослих завдяки властивостям активізувати емоційну та інтелектуальну сферу в умовах невизначеності смислів.

Ключові слова: навчальна програма; освіта дорослих; методики артроз витку; актуалізація потенціалу особистості; VUCA-світ; економічна поведінка.

\section{1. ВСТУП / INTRODUCTION}

Постановка проблеми. У період євроінтеграційних трансформацій українське суспільство знаходиться на такому рівні поляризації думок стосовно реформ у всіх сферах, що успішність реформ і розвиток, в тому числі й економічний, багато в чому залежить від довіри до державних інститутів, органів влади, 3МI, партнерів з бізнесу в Україні і закордоном. Стійкий економічний розвиток прямо пов'язаний з такими соціальнопсихологічними концептами як довіра, соціальний капітал, громадянська активність, громадянська ідентичність.

Медіа суттєво впливають на економічну поведінку, формуючи суспільні стереотипи, переконання, цінності. Інформація надходить через смартфони практично увесь час, коли ми не спимо. Під час високих швидкостей, відкритого доступу до знань та інформації, існування складних систем соціальних стосунків та соціальних медіа, в умовах браку часу на перевірку отриманої інформації свідомість громадян перевантажена настільки, що необхідними є хоча б базові навички захисту 
себе від деструктивних впливів медіа. Отже, неминуче постає питання про довіру новинним медіа.

Однією із функцій громадянської активності як компоненту громадянської ідентичності є контроль корупції і корупційної поведінки, що підривають довіру i соціальний капітал, необхідні для стійкого економічного розвитку. Громадянську активність як можливість впливати на політичні процеси та рішення можна розглядати як один 3 механізмів регулювання довіри до уряду та державних інститутів серед громадян. В Україні проблема довіри до уряду та державних інститутів давно пов'язана 3 державною безпекою та територіальною цілісністю країни. Тривалий період часу рівень корупції в українському суспільстві був досить високим, а корупційна поведінка стала практично нормативною. Зміна такої «нормативності» корупційної поведінки $є$ необхідною умовою подальшого економічного розвитку держави. Це зумовлює необхідність підготовки фахівців до такої поведінки, що сприяє сталому економічному розвитку.

Малопередбачуваний світ, який є нашим сьогоденням, у 1987 році в Армійському воєнному коледжі Сполучених Штатів Америки запропонували називати VUCA-світом, з 2002 року цей термін почали застосовувати частіше. Абревіатура відображає чотири характеристики сучасного світу: Volatility - минливість, Uncertainty - невизначеність, Complexity - складність, Ambiguity - багатозначність.

В умовах VUCA-світу ситуації уразливості $€$ неминучими, умовами угод неможливо передбачити усі ризики. VUCA-світ в будь-який момент може змусити функціонувати в непередбачуваних умовах, в яких кожен $\epsilon$ уразливим і залежним від поведінки партнерів і необхідним є створення нових стратегій поведінки, адже звичні стратегії вже не є ефективними. Поведінка партнерів з професійної діяльності в таких екстремальних ситуаціях залежить від спільних цінностей і взаємовигідних стратегій.

Поведінка, яка відповідає стратегії виживання, протистоїть стратегії розвитку. Виживання передбачає як норму «топити» інших для рятування себе - це стратегія збереження життя в екстремальних ситуаціях. Така стратегія, як правило, не містить довготривалого планування. Стратегію помноження своїх ресурсів за рахунок поглинання або підпорядкування інших можна вважати більш складною формою стратегії виживання, адже в ній є довготривале планування. Стратегія розвитку, навпаки, передбачає збереження балансу інтересів всіх сторін, спільні цінності та норми поведінки партнерів.

Професійна самореалізація та успішність в умовах VUCA-світу залежать від того, хто буде з нами співпрацювати. Стратегія виживання 
відштовхує потенційних партнерів, спільна діяльність з якими могла б вивести всі сторони взаємодії на новий рівень функціонування.

Багато рішень в умовах VUCA-світу, коли неможливо розрахувати всі ризики, доводиться приймати на основі довіри. Довіра, як обумовлена, так й безумовна, стає необхідною умовою економічної та професійної самореалізації. Водночас, орієнтиром для особистісного і професійного розвитку в VUCA-світі можуть і повинні бути цінності. Усвідомлення співвідношення цінностей на рівні нормативних ідеалів та індивідуальних пріоритетів можливо за допомогою використання традиційних методів арттерапії. Особливо ефективно використовувати в освіті дорослих методики, засновані на застосуванні метафор (наприклад, метафора сходинок, колесо балансу життя, карта досягнень тощо).

Методики актуалізації потенціалу особистості, що застосовуються в післядипломній освіті фахівців, скоріше можна вважати методиками артрозвитку, ніж арттерапії. Необхідність відмовлятися від перевірених звичних способів виконання роботи часто пов'язана зі стресами, зміною місця роботи, тимчасовим безробіттям, зміною сфери діяльності, професії. Фахівцям доводиться постійно прагнути нових знань, опановувати нові навички, щоб залишатися затребуваними.

Професійні кризи в умовах непередбачуваного VUCA-світу часто пов'язані з дестабілізацією професійної ідентичності. Коли професійна ідентичність $є$ базовою в системі соціальних ідентичностей особистості професійна криза може призвести до зміни професійній сфері діяльності для виходу з кризи, який є неможливий без одночасного збалансування системи соціальних ідентичностей. Прикладом причини такої кризи може бути несумісність норм і цінностей професійного середовища з нормами і цінностями особистості. В такому випадку, фахівці змінюють сферу діяльності з метою «самозбереження».

Перехід з однієї сфери діяльності в іншу дозволяє фахівцям збагатитися крос-секторальним досвідом, розвинути різнобічний потенціал для подальшої ефективної реалізації. Досвід, отриманий в одній сфері, може бути тим, на що можна спиратися під час проходження професійної кризи в іншій сфері. Стратегії поведінки, які були успішно застосовані в інших сферах, можуть стати виграшними саме тому, що в теперішній сфері такі стратегії раніше не застосовувалися.

Таким чином, актуалізація, розвиток та реалізація потенціалу особистості часто відбуваються в процесі переходу з однієї професійної сфери в іншу. В процесі переживання професійної кризи у фахівців знижується психологічне благополуччя і вони потребують психологічної 
підтримки, яка може бути включена в систему післядипломної освіти i частково реалізована методами артрозвитку.

Аналіз останніх досліджень і публікацій. VUCA-cвіт, в якому ми зараз живемо, пропонує таку множинність сенсів, що, на наш погляд, візуальна метафора може застосовуватися як один з найбільш ефективних інструментів, шо дозволяє пов'язати особисті сенси з неоднозначними, такими, що постійно змінюються, сенсами VUCA-світу, не гублячи при цьому свою ідентичність і не нехтуючи своїми цінностями. Орієнтація на свої цінності в невизначеному VUCA-світі потребує усвідомлення цих цінностей та цілей як орієнтира під час вибору стратегї поведінки і варіантів вчинків в кожній конкретній ситуації. Ми розглядаємо візуальну метафору як невід'ємний компонент освіти дорослих.

О. Вознесенська [9] наголошує, що звернення до емоційної сфери людини через метафору актуалізує емоційні та поведінкові патерни, притаманні їй. Здатність метафори через творчість обійти критику свідомості надає можливість дослідити власні несвідомі процеси, приховані ідеї і стани, бажані соціальні ролі та форми поведінки, що витіснені або мало проявлені у повсякденному житті. Символічна мова дозволяє виразити свої почуття, по-новому поглянути на ситуацію та проблеми і завдяки цьому знайти шлях до їх вирішення.

О.Угрин [26] розглядає метафору як інструмент активізації емоційної та інтелектуальної сфер. Вона відмічає, що до метафори наше мислення звертається тоді, коли немає готових рішень, пояснень, смислів. Саме наявність ситуації з багатьма невідомими провокує процес створення метафори. У процесі її створення задіяні такі логічні операції як порівняння і аналіз за участю уяви, що сприяє розумінню. Ефективність розуміння через метафору обумовлена її здатністю активізувати емоційну та інтелектуальну сфери.

Іншим потужним методом звернення до емоційної сфери та несвідомого є малювання каракулів. О. Молчанова [19] описує малювання каракулів як неусвідомлений спосіб винесення травмівних переживань назовні, звільнення від надлишку емоцій та почуттів. Кожен малюнок через лінії та форми відображає несвідоме. Проекція почуттів на зовнішні об'єкти сприяє визнанню своїх почуттів. Зображення прискорюють вербалізацію переживань. Малювання каракулів сприяє підвищенню самооцінки, впевненості у власних можливостях, зачіпає сферу творчого потенціалу особистості, знижує рівень тривожності, сприяє особистісному зростанню. На думку Л. Лєбєдєвої [13] люди під час малювання каракулів, створюють не образ чи картинку, а висловлюють свої почуття. Каракулі 
мають високий діагностичний потенціал, розглядаються як індикатор соціальної зрілості особистості.

Малювання каракулів у групі сприяє формуванню шанобливого ставлення до виявів ініціативи 3 боку інших членів групи. Учасникам групи не потрібно хвилюватися про якість малюнка, його оцінку іншими, з'являється можливість зняти з себе відповідальність та побути в ролі дитини [19]. О. Вознесенська [9] підкреслює те, що малювання карлючок це потужна регресія у той період, коли будь-які дії дитини (плямування, каракулі) викликали захоплення й розчулення у батьків. Тому, застосування цієї методики викликає радість також і у дорослих [9].

О. Молчанова [19] зазначає, що малювання каракулів, ліній та геометричних форм може стати складовою будь-якої системи освіти кожного педагога і психолога, здатного до поєднання педагогічних та психотерапевтичних методів з метою активізації особистісного розвитку, що сприятиме розвитку ціннісного ставлення як до власної особистості, так і до оточуючих.

\section{2. МЕТА ТА ЗАВДАННЯ / AIM AND TASKS}

Метою статті $€$ презентація навчальної програми спецкурсу «Психологія економічної поведінки фахівця», який призначено для педагогічних кадрів освітніх організацій, викладачів інститутів післядипломної освіти, практичних психологів, аспірантів, а також усіх, хто цікавиться проблемами економічної поведінки сучасного фахівця. Спецкурс містить комплекс методик артрозвитку для актуалізації потенціалу особистості фахівця в освіті дорослих. Методики артрозвитку базуються на принципах арттерапії, але адаптовані під завдання освіти дорослих.

Спецкурс було розроблено та впроваджено на кафедрі психології управління Центрального інституту післядипломної освіти ДЗВО «Університет менеджменту освіти».

Відповідно до зазначеної мети у статті поставлено такі завдання: 1) провести міждисциплінарний аналіз сучасних досліджень з економічної поведінки фахівця; 2) підібрати методики артрозвитку дорослої особистості для застосування в освіті дорослих.

\section{TЕОРЕТИЧНІ ОСНОВИ ДОСЛІДЖЕННЯ / THЕ THЕОRЕTICAL BACKGROUNDS}

В інформаційній складовій навчальної програми розглядаються такі соціально-психологічні та економічні поняття як економічна поведінка, довіра в економічних та міжетнічних взаєминах, соціальний капітал, 
психологічне благополуччя, корупційна поведінка, громадянська активність. Коротко розглянемо основні.

Економічною поведінкою називають поведінку, що викликана економічними стимулами. Будь-якому вчинку людини зазвичай передує сприйняття, обмірковування, розуміння ситуації і себе в ній, тобто когнітивні компоненти, суб'єктивне ставлення, забарвлене почуттями, тобто афективні компоненти, i, врешті-решт, дія або навпаки їі зміст, тобто конативні компоненти. Розглядаючи економічну поведінку, як правило, для аналізу виділяють ці три взаємопов'язані складові [14].

Р. Маєр, Дж. Девіс, Ф. Шурман [32] визначають довіру як готовність однієї сторони до вразливості від дій іншої сторони на підставі очікування того, що інша сторона здійснить важливу для того, хто довіряє, дію, незалежно від його/їі можливості проконтролювати цю дію.

С. Кастелфранчі и Р. Фалконе [29] виділяють обумовлену і безумовну довіру. Обумовлена довіра пов'язана з раціональним міркуванням, на відміну від безумовної довіри, яка $є$ емоційною та автоматичною. При обумовленій довірі індивіди вирішують довіряти іншій людині на основі наступних чотирьох факторів: 1) загальні цілі того, хто довіряє, і того, кому довіряють, 2) залежність того, хто довіряє, від того, кому довіряють, 3) сприйняття того, кому довіряють, як компетентного і нешкідливого, 4) існування зовнішніх умов, які сприяють або перешкоджають досягненню мети. Безумовна довіра $\epsilon$ автоматичною, ненавмисною, несвідомою реакцією на стимул. Якщо поведінка довіри закріпилася за певних обставин, схожі обставини будуть слугувати стимулом для довіри в майбутньому [33].

В. ван Рааї [34] відзначає важливість довіри для розвитку економіки. Необхідно, щоб споживачі довіряли уряду і приватним інститутам, щоб інститути довіряли один одному і уряду. У разі недовіри укладається менша кількість угод або вони взагалі не укладаються, застосовується більше юридичних пересторіг, які призводять до підвищення вартості та уповільнення угод, знижується ефективність.

3 погляду В. ван Рааї [34] можна виділити країни з високою довірою і країни $з$ низькою довірою. Для країн 3 високою довірою характерним $\epsilon$ високий рівень спонтанної комунікації. Індивіди у цих країнах здатні будувати міцні стосунки за межами сім'ї. У таких країнах створюються великі корпорації сучасного суспільства. Серед людей у країнах з низькою довірою відсутня схильність довіряти кому-небудь за межами сім'ї або клану. У таких країнах спостерігається тенденція створювати маленькі сімейні фірми. Традиційно такі регіони як Китай і південна Італія $\epsilon$ 
країнами з низькою довірою, в той час як Японія, Німеччина та США $\epsilon$ країнами з високим рівнем довіри.

У контексті взаємодії з фінансовими інститутами В. ван Рааї [34] визначає довіру як переконання в тому, що банк, страхова компанія або інший фінансовий інститут буде діяти у відповідності 3 інтересами споживача, не буде зловживати недоліком інформації у споживачів і не буде переслідувати власні інтереси. Довіра особливо необхідна, коли якість фінансових продуктів та послуг неможливо повністю оцінити перед покупкою. Так, наприклад, у довірі до страхових компаній В. ван Рааї [34] виділяє наступні детермінанти: компетентність (продукт, маркетинг, знання клієнта, чесність), надійність (доброзичливість, прозорість, узгодженість цінностей) і стабільність (розмір, сила).

Для продуктивного функціонування економіки держави важливим чинником $\epsilon$ ефективна робота системи оподаткування. Е. Кирхлер, Е. Хелзл, I. Ваал [31] в низці досліджень показали важливість довіри для підпорядкування платників податків. Ними була запропонована модель «слизького схилу», яка пояснює податкову поведінку. Дана модель складається 3 двох компонентів: сприймальної сили органів влади (наприклад, податковий аудит) та довіри до органів влади.

Е. Кирхлер, Е. Хелзл, І. Ваал [31] визначають довіру як думку індивідів і соціальних груп про те, що податкова влада діє відповідно до загального блага. Сила органів влади визначається як сприймальна здатність органів влади виявити податкові порушення і покарати. Відповідно до моделі «слизького схилу» податкове підпорядкування досягає максимуму або при максимальній довірі або при максимальній силі податкової влади, а також при максимальних показниках як довіри, так і сили податкової влади. Відповідно, податкове підпорядкування знижується до мінімуму при поєднанні мінімальної довіри з мінімальною силою податкової влади.

Б. Кшивош-Ринкевіч и А. Залевська [35] виділяють 6 munis громадянської поведінки:

- пасивна громадянська поведінка містить поведінку, що виражає національну ідентичність, почуття приналежності до держави або нації, повагу до національних символів і патріотизм;

- напівактивна громадянська поведінка виражається у відданості державі і державним інститутам, а також в участі у виборах (голосуванні);

- активна соціальна громадянська поведінка виражається у волонтерській роботі на користь місцевого суспільства i оточуючого середовища, представленні місцевого співтовариства і вирішенні місцевих проблем; 
- активна політична громадянська поведінка містить бажання приймати участь в управлінні через членство в політичній партії;

- активна, спрямована на зміни громадянська поведінка виявляється у спробах моніторингу дій влади, законних і незаконних протестах;

- активна особистісно орієнтована громадянська поведінка спрямована на особистісний розвиток, незалежність, фінансову стабільність і підприємництво.

У сучасному світі інформаційних технологій важко переоцінити роль медіа в громадянській активності. Використання соціальних медіа пов'язано із поширенням соціальних протестів у багатьох містах по всьому світу, включаючи Київ, Москву, Стамбул, Анкару, Каїр, Тріполі, Афіни, Мадрид, НьюЙорк, Лос-Анджелес, Гонконг. Дж. Джост з колегами [30], проаналізувавши рухи протесту в США, Іспанії, Туреччині і Україні, відмічають, що:

1) платформи соціальних медіа сприяють обміну інформацією, яка $\epsilon$ необхідною для координування акцій протесту, такою як новини щодо транспорту, страйків, наявності поліції, насилля, медичного обслуговування і юридичної підтримки;

2) платформи соціальних медіа сприяють обміну емоційним i мотиваційним контентом в підтримку чи протидію акціям протестів, включаючи повідомлення, що містять гнів, соціальну ідентифікацію, ефективність групи, позбавлення, турботу про справедливість, правосуддя, а також ідеологічні теми;

3) структурні характеристики онлайнових соціальних мереж можуть відрізнятися. Будучи функціями політичної ідеології, вони пов'язані 3 інформаційним впливом і успіхом або невдачею організації протестів.

\section{4. МЕТОДИ ДОСЛІДЖЕННЯ / RESEARCH METHODS}

Було проведено аналіз міждисциплінарних досліджень результатом якого став синтез сучасних здобутків соціальної психології, економіки, арттерапії задля їхнього впровадження в освіту дорослих та розвиток дорослої особистості.

\section{5. РЕЗУЛЬТАТИ ДОСЛІДЖЕННЯ / RESEARCH RESULTS}

Теоретичні концепції, представлені в рамках спецкурсу «Психологія економічної поведінки фахівця», та їх практичне застосування розглядаються як з погляду соціальної психології, так і з погляду економіки. Мета спецкурсу полягає у формуванні навичок, необхідних для конструктивної економічної поведінки, що сприяє росту економічної довіри в суспільстві.

У результаті опанування змісту даного спецкурсу фахівці отримають 
знання щодо особливостей довіри в економічних та міжетнічних стосунках; усвідомлять особливості функціонування соціального капіталу в різних спільнотах та роль громадянської активності в забезпеченні сталого економічного розвитку; зможуть розвинути вміння та навички попередження корупційної поведінки як такої, що підриває економічну довіру та загрожує функціонуванню соціального капіталу.

\section{Програма навчальної дисципліни}

Змістовий модуль 1. Економічна поведінка сучасного фахівця та ї̈ соціально-психологічні чинники

Тема 1.Економічна поведінка та прийняття економічних рішень сучасними фахівцями.

Економічна поведінка та їі чинники (когнітивні, афективні, мотиваційновольові). Ризики при прийнятті економічних рішень. Роль медіа у формуванні економічної поведінки сучасного фахівця. Атрибуція в економічної поведінки. Емоції та звички при прийнятті економічних рішень. Види економічних емоцій. Мотиви економічної поведінки. Заощадження домашніх господарств. Альтруїстична поведінка. Порівняння альтернатив. Ризик та готовність ризикувати. Ціна ризику та ризикова ситуація. Суперечливість та альтернативність як чинники прийняття ризикованого рішення. Прийняття економічних рішень в VUCA-світі [14], [15], [17], [18], [20], [21], [24].

Тема 2. Довіра в економічних відносинах як чинник економічної поведінки.

Види довіри: обумовлена та безумовна, стратегічна та моралістична, спеціалізована та генералізована. Чинники довіри. Довіра інститутам. Довіра новинним медіа. Довіра державним інститутам як чинник податкової поведінки. Довіра в міжетнічних економічних відносинах. Культури з високою довірою та культури з низькою довірою. Механізми контролю економічної поведінки в культурах 3 низькою довірою та в культурах з високою довірою. Інституційні та міжособистісні механізми контролю економічної поведінки. Довіра в економічних відносинах в VUCA-світі. Ситуації економічної вразливості та економічна довіра. Важливість довіри для розвитку економіки [2], [29], [31], [33], [34], [6], [5].

Тема 3. Взаємозв'язок економічної поведінки та соціального капіталу.

Соціальний капітал та його застосування в політиці. Поєднання індивідуального і колективного аспектів соціального капіталу. Соціальний капітал відносин і системний соціальний капітал. Соціальний капітал відносин: соціальний капітал положення, соціальний капітал довіри, соціальний капітал зобов'язань. Системний соціальний капітал: системний контроль, системна довіра, системна мораль. Функціонування соціального 
капіталу в різних спільнотах. Соціальний капітал в спільнотах іммігрантів і біженців [14], [17], [18], [1], [3], [15], [21], [23].

Тема 4. Психологічне благополуччя як чинник економічної поведінки. Грошові патології.

Економічна поведінка психологічно благополучної особистості. Психологічні причини боргів. Емоційна основа грошової патології: провина, контроль, безпека. Емоційне значення грошей: безпека, влада, любов і свобода. Безпека: скнари, подвижники, мисливці за знижками, колекціонери-фанатики. Влада: маніпулятори, будівники імперій, хрещені батьки. Любов: покупці любові, продавці любові, викрадачі любові. Свобода: покупці свободи, борці за свободу. Причини грошових розладів. Чинники грошової поведінки [8], [14], [17], [22], [25], [27].

Змістовий модуль 2. Громадянська активність фахівця як чинник конструктивної економічної поведінки

Тема 5.Громадянська активність фахівця в забезпеченні конструктивної економічної поведінки.

Типи громадянської активності. Пасивна громадянська поведінка. Напівактивна громадянська поведінка. Активна громадянська поведінка. Громадянська активність та соціальні медіа. Громадянська активність як чинник довіри до державних інститутів. Громадянська активність як чинник ефективності впровадження реформ. Громадянська активність як чинник економічного розвитку. Громадянська поведінка як компонент громадянської ідентичності. Соціально-психологічна модель громадянської ідентичності [7], [14], [17], [18], [28], [30], [35], [5], [4], [15], [20].

Тема 6. Психологія корупційної поведінки та ї̈ попередження в діяльності фахівця.

Соціально-психологічні детермінанти корупційної поведінки. Когнітивна психологія корупційної поведінки. Прийняття корупційних рішень. Влада та корупційна поведінка. Класифікація корупції: хабарництво, відкат, підкуп, здирництво, непотизм, фаворитизм. Концепція трансакційних витрат. Наслідки корупції: соціальні, економічні, владні, політичні, правові, міжнародні, психологічні. Попередження корупційної поведінки. Корупційна поведінка та довіра до влади та державних інститутів. Корупційна поведінка та соціальний капітал. Індекси корупції. Діяльність Transparency International [10], [11], [14], [17], [21]. 
Таблиця 1

\section{Структура навчальної дисципліни}

\begin{tabular}{|c|c|c|c|c|}
\hline \multirow{3}{*}{ Назви змістових модулів і тем } & \multicolumn{4}{|c|}{ Кількість годин } \\
\hline & \multirow{2}{*}{$\begin{array}{l}0 \\
0 \\
0 \\
0 \\
D\end{array}$} & \multicolumn{3}{|c|}{ У тому числі } \\
\hline & & л & пр & $\mathrm{cpc}$ \\
\hline \multicolumn{5}{|c|}{$\begin{array}{l}\text { Змістовий модуль 1. Економічна поведінка сучасного фахівця та її соціально- } \\
\text { психологічні чинники }\end{array}$} \\
\hline $\begin{array}{l}\text { Тема 1. Економічна поведінка та прийняття економічних } \\
\text { рішень сучасними фахівцями }\end{array}$ & 15 & 2 & 2 & 11 \\
\hline $\begin{array}{l}\text { Тема 2. Довіра в економічних відносинах як чинник } \\
\text { економічної поведінки }\end{array}$ & 15 & 2 & 4 & 9 \\
\hline $\begin{array}{l}\text { Тема 3. Взаємозв'язок економічної поведінки та соціального } \\
\text { капіталу }\end{array}$ & 15 & 2 & 2 & 11 \\
\hline $\begin{array}{l}\text { Тема 4. Психологічне благополуччя як чинник економічної } \\
\text { поведінки. Грошові патології }\end{array}$ & 15 & 2 & 4 & 9 \\
\hline Усього годин за змістовим модулем 1 & 60 & 8 & 12 & 40 \\
\hline \multicolumn{5}{|c|}{$\begin{array}{l}\text { Змістовий модуль 2. Громадянська активність фахівця як чинник конструктивної } \\
\text { економічної поведінки }\end{array}$} \\
\hline $\begin{array}{l}\text { Тема 5. Громадянська активність фахівця в забезпеченні } \\
\text { конструктивної економічної поведінки }\end{array}$ & 15 & 2 & 4 & 9 \\
\hline $\begin{array}{l}\text { Тема 6. Психологія корупційної поведінки та її попередження в } \\
\text { діяльності фахівця }\end{array}$ & 15 & & 4 & 11 \\
\hline Усього годин за змістовим модулем 2 & 30 & 2 & 8 & 20 \\
\hline PA30M: & 90 & 10 & 20 & 60 \\
\hline
\end{tabular}

Таблиця 2

Теми та зміст практичних занять

\begin{tabular}{|c|c|c|c|}
\hline $\begin{array}{l}\text { № } \\
3 / \Pi\end{array}$ & Теми практичних занять & Зміст практичних занять & Години \\
\hline 1 & 2 & 3 & 4 \\
\hline \multicolumn{4}{|c|}{$\begin{array}{l}\text { Змістовий модуль 1. Економічна поведінка сучасного фахівця та її соціально- } \\
\text { психологічні чинники }\end{array}$} \\
\hline 1 & $\begin{array}{l}\text { Тема 1. Економічна поведінка та } \\
\text { прийняття економічних рішень } \\
\text { сучасними фахівцями }\end{array}$ & $\begin{array}{l}\text { Аналіз професійних ситуацій, які } \\
\text { містять традиційні та інноваційні } \\
\text { практики прийняття економічних } \\
\text { рішень }\end{array}$ & 2 \\
\hline 2 & $\begin{array}{l}\text { Тема 2. Довіра в економічних } \\
\text { відносинах як чинник економічної } \\
\text { поведінки }\end{array}$ & $\begin{array}{l}\text { Аналіз останніх соціологічних } \\
\text { досліджень довіри як чинника } \\
\text { економічного розвитку } \\
\text { особистості, організації та } \\
\text { держави }\end{array}$ & 4 \\
\hline
\end{tabular}


Продовження табл. 2

\begin{tabular}{|c|c|c|c|}
\hline 1 & 2 & 3 & 4 \\
\hline 3 & $\begin{array}{l}\text { Тема 3. Взаємозв'язок економічної } \\
\text { поведінки та соціального капіталу }\end{array}$ & $\begin{array}{l}\text { Діагностика власного } \\
\text { соціального капіталу та аналіз } \\
\text { можливостей його розвитку }\end{array}$ & 2 \\
\hline 4 & $\begin{array}{l}\text { Тема 4. Психологічне благополуччя } \\
\text { як чинник економічної поведінки. } \\
\text { Грошові патології }\end{array}$ & $\begin{array}{l}\text { Аналіз соціально-психологічних } \\
\text { чинників грошових патологій }\end{array}$ & 4 \\
\hline \multicolumn{4}{|c|}{ Усього годин за змістовим модулем 1} \\
\hline \multicolumn{4}{|c|}{$\begin{array}{l}\text { Змістовий модуль 2. Громадянська активність фахівця як чинник конструктивної } \\
\text { економічної поведінки }\end{array}$} \\
\hline 5 & $\begin{array}{l}\text { Тема 5. Громадянська активність } \\
\text { фахівця в забезпеченні } \\
\text { конструктивної економічної } \\
\text { поведінки }\end{array}$ & $\begin{array}{l}\text { Розробка заходів громадянської } \\
\text { активності в соціальних } \\
\text { мережах }\end{array}$ & 4 \\
\hline 6 & $\begin{array}{l}\text { Тема 6. Психологія корупційної } \\
\text { поведінки та її попередження в } \\
\text { діяльності фахівця }\end{array}$ & $\begin{array}{l}\text { Розробка рекомендацій щодо } \\
\text { попередження корупційної } \\
\text { поведінки у професійних } \\
\text { ситуаціях }\end{array}$ & 4 \\
\hline \multicolumn{4}{|c|}{ Усього годин за змістовим модулем 2} \\
\hline & & Разом: & 20 \\
\hline
\end{tabular}

Завдання для самостійної роботи містять опрацювання питань, які не розглядаються на аудиторних заняттях, та індивідуально-дослідницькі завдання.

\section{Таблиця 3}

\section{Самостійна робота}

\begin{tabular}{|c|c|c|}
\hline Теми для самостійної роботи & Зміст самостійної роботи & Години \\
\hline 1 & 2 & 3 \\
\hline \multicolumn{3}{|c|}{$\begin{array}{l}\text { Змістовий модуль 1. Економічна поведінка сучасного фахівця та ї̈ соціально- } \\
\text { психологічні чинники }\end{array}$} \\
\hline $\begin{array}{l}\text { Тема 1. Економічна } \\
\text { поведінка та прийняття } \\
\text { економічних рішень } \\
\text { сучасними фахівцями }\end{array}$ & $\begin{array}{l}\text { Проаналізуйте переваги раціонального та } \\
\text { емоційного прийняття рішень в умовах } \\
\text { сучасного VUCA-світу. Опишіть ризики } \\
\text { раціонального та емоційного прийняття } \\
\text { рішень. } \\
\text { Індивідуально-дослідницьке завдання: } \\
\text { Розробить рекомендації стосовно } \\
\text { прийняття економічних рішень в } \\
\text { організаціях, беручи до уваги традиційні } \\
\text { та інноваційні практики та норми }\end{array}$ & 11 \\
\hline
\end{tabular}




\section{Продовження табл. 3}

\begin{tabular}{|c|c|c|}
\hline 1 & 2 & 3 \\
\hline $\begin{array}{l}\text { Тема 2. Довіра в економічних } \\
\text { відносинах як чинник } \\
\text { економічної поведінки }\end{array}$ & $\begin{array}{l}\text { Проаналізуйте, як встановлення і розробка } \\
\text { зарубіжних контактів на індивідуальному } \\
\text { рівні розширять ваші можливості та роль } \\
\text { довіри в цьому процесі. Визначте чинники } \\
\text { довіри в міжнародному економічному } \\
\text { контексті. Проаналізуйте роль довіри в } \\
\text { організаційному розвитку та можливі } \\
\text { перешкоди. } \\
\text { Індивідуально-дослідницьке завдання: } \\
\text { Розробить принципи взаємодії в } \\
\text { організації задля розвитку довіри та } \\
\text { засоби подолання перешкод }\end{array}$ & 9 \\
\hline $\begin{array}{l}\text { Тема 3. Взаємозв'язок } \\
\text { економічної поведінки та } \\
\text { соціального капіталу }\end{array}$ & $\begin{array}{l}\text { Проаналізуйте фактори, що } \\
\text { перешкоджають розвитку вашого } \\
\text { соціального капіталу у кожній сфері. } \\
\text { Визначте роль соціального капіталу } \\
\text { кожного із співробітників у розвитку } \\
\text { соціального капіталу організації, } \\
\text { розширюючи ії можливості. Розробить } \\
\text { принципи взаємодії в організації, щоб у } \\
\text { співробітників було бажання максимально } \\
\text { вкладати ресурси власного соціального } \\
\text { капіталу в соціальний капітал організації. } \\
\text { Індивідуально-дослідницьке завдання: } \\
\text { Розробіть план підвищення свого } \\
\text { соціального капіталу в тих сферах, в яких } \\
\text { вам його не вистачає. Розробить принципи } \\
\text { взаємодії в організації, щоб у } \\
\text { співробітників було бажання максимально } \\
\text { вкладати ресурси власного соціального } \\
\text { капіталу в соціальний капітал організації }\end{array}$ & 11 \\
\hline $\begin{array}{l}\text { Тема 4. Психологічне } \\
\text { благополуччя як чинник } \\
\text { економічної поведінки. } \\
\text { Грошові патології }\end{array}$ & $\begin{array}{l}\text { Проаналізуйте економічні чинники } \\
\text { психологічного благополуччя. } \\
\text { Проаналізуйте вплив грошових патологій } \\
\text { на особливості економічної поведінки та } \\
\text { прийняття економічних рішень. } \\
\text { Індивідуально-дослідницьке завдання: } \\
\text { Розробить програму підвищення та } \\
\text { збереження психологічного благополуччя } \\
\text { організації }\end{array}$ & 9 \\
\hline \multicolumn{2}{|c|}{ Усього годин за змістовим модулем 1} & 40 \\
\hline
\end{tabular}


Продовження табл. 3

\begin{tabular}{|c|c|c|}
\hline 1 & 2 & 3 \\
\hline \multicolumn{3}{|c|}{$\begin{array}{l}\text { Змістовий модуль 2. Громадянська активність фахівця як чинник конструктивної } \\
\text { економічної поведінки }\end{array}$} \\
\hline $\begin{array}{l}\text { Тема 5. Громадянська } \\
\text { активність фахівця в } \\
\text { забезпеченні конструктивної } \\
\text { економічної поведінки }\end{array}$ & $\begin{array}{l}\text { Проаналізуйте, яку роль відіграють } \\
\text { соціальні медіа та соціальні мережі в } \\
\text { розвитку вашого соціального капіталу та } \\
\text { можливостях громадянської активності. } \\
\text { Індивідуально-дослідницьке завдання: } \\
\text { Розробить алгоритм громадянської } \\
\text { активності в соціальних мережах на } \\
\text { конкретному прикладі. }\end{array}$ & 9 \\
\hline $\begin{array}{l}\text { Тема 6. Психологія } \\
\text { корупційної поведінки та її } \\
\text { попередження в діяльності } \\
\text { фахівця }\end{array}$ & $\begin{array}{l}\text { Чинники корупційної поведінки на рівні } \\
\text { держави, організації та особистості. } \\
\text { Індивідуально-дослідницьке завдання: } \\
\text { Проаналізуйте види корупційної } \\
\text { поведінки та ї̈ наслідки. } \\
\text { Розробить стратегію протидії корупційній } \\
\text { поведінці в організації }\end{array}$ & 11 \\
\hline \multicolumn{2}{|c|}{ Усього годин за змістовим модулем 2} & 20 \\
\hline & Разом: & 60 \\
\hline
\end{tabular}

\section{Методики артрозвитку як методики актуалізації потенціалу особистості}

«Календар моїх емоцій» (І. Бондаревська)

Мета: усвідомлення динаміки своїх емоційних станів та причин їх виникнення.

Треба взяти парну кількість невеликих прямокутних аркушів паперу $(4,6,8)$, які після завершення вправи необхідно з'єднати з заднього боку малюнків прозорим скотчем. Кожен день на одному аркуші треба малювати за допомогою кольорових олівців лініями свої емоції, почуття, стани. Бажано уникати зображення конкретних символів або застосовувати їх мінімально і малювати лише тоді, коли це дуже важливо. Заповненість аркушу лініями, їх кольори і різноманіття - за бажанням. Закінчувати малюнок краще ввечері, після чого до нього вже не повертатися. В останній парний день аркуші з'єднуються прозорим скотчем з заднього боку в одну полосу. Які емоції у вас викликає це зображення, поєднання всіх малюнків? Які емоції переважають? Чи хочете ви змінити спектр ваших емоцій? Що саме викликало у вас ті чи інші емоції в цей проміжок часу? 
М. Долінова [12] під час опису схожої методики «Щоденник каракулів» зазначає, що результатами такого малювання можуть бути незвичайні чи неочікувані ідеї, прояснення власних почуттів, більш точне розуміння ситуації, покращення емоційного самопочуття за рахунок вивільнення почуттів в ході малювання.

Малюнок «Почуття» (О. Молчанова [19], доповнено І. Бондаревською).

Мета: усвідомлення особливостей переживання емоцій, станів та почуттів.

Аркуш формату A4 складається так, щоб на ньому утворилось 8 клітинок, у яких учасники мають намалювати свої емоції та почуття гніву, радості, спокою, депресії, енергійності, жіночості/мужності, хвороби та будь-якого стану на власний вибір. Кожен малюнок виконується лініями на власний розсуд. Це може бути одна лінія, багато ліній, можливо покрити всю клітинку лініями, якщо саме це передає ваші почуття. При цьому не можна малювати будь-які символи (зірки, серця тощо). Використовувати треба лінії, які передають ваш емоційний стан (ламані, плавні). Для отримання зворотного зв'язку учасники викладають свої малюнки в коло, обговорюють емоції, стани та почуття на всіх малюнках. Малюнки роблять почуття видимими.

Порівняйте малюнки гніву, радості тощо. Що спільного та чим відрізняються зображення одних и тих само емоцій у різних людей? Які емоції ви дозволяєте собі проявляти, а які пригнічуєте? В завершення вправи намалюйте каракулями свій емоційний стан зараз.

Вправа «П'ять ліній» (О. Молчанова [19]).

Мета: зняття психоемоційного напруження, підвищення самооцінки, розвиток уяви та навичок комунікації.

Вправа проводиться в парах. Кожен учасник обирає олівець одного кольору і на аркуші паперу малює 5 ліній. Вони можуть бути товстими чи тонкими, короткими чи довгими, прямими чи звивистими, але вони не мають складатися в конкретний малюнок. Потім кожен учасник перемальовує свої ж лінії на 9 аркушів. Таким чином, виходить 10 однакових малюнків. Учасники обмінюються малюнками та мають перетворити лінії в картини. Початкові 5 ліній повинні бути видними та залишитись того ж кольору, якими їх намалював автор. Всі 5 ліній повинні бути включеними в малюнок, незалежно від того, яким би дивним він не вийшов.

Всі завершені малюнки повертаються авторам, група поділяється на пари, і у парах учасники аналізують малюнки (20 на пару). Що вони помічають в спільної творчості? Чи є подібні теми, подібні об'єкти? Які малюнки було створити простіше - перші чи останні? 
Малюнок «Карта досягнень» (М. Ткалич [25]).

Мета: усвідомити свої особистісні і професійні сфери самореалізації, відмітити свої досягнення, побачити нові можливості подолання перешкод, визначити важливі ресурси для подальшого розвитку. Визначити пріоритетні сфери свого гендерного самоствердження.

Намалюйте карту ваших досягнень та успіхів, минулих, теперішніх і майбутніх в сфері кар'єри та професійного розвитку, материнства та батьківства, прагнення бути хорошою господинею та господарем, сферу міжособистісних стосунків, привабливої зовнішності і додайте ще кілька важливих для вас сфер самореалізації. Ваші успіхи і досягнення позначте як пункти призначення, в котрих ви вже були або куди хотіли би попасти. Позначте також проміжні успіхи. Придумайте і напишіть назви для досягнень, до яких ви прагнете. Намалюйте також вулиці і дороги, якими ви підете до своїх досягнень. Це будуть короткі чи обхідні шляхи? Які перешкоди треба буде долати? На яку допомогу ви розраховуєте?

Питання для обговорення: 1) Які почуття викликає у вас ваша карта?; 2) Де знаходяться найбільш важливі успіхи і досягнення?; 3) Де чекає небезпека?; 4) Які у вас $є$ ресурси для досягнення бажаного?; 5) Які у вас $є$ ресурси для подолання перешкод?

Аналіз вправи можливо доповнити авторською розробкою Наталії Павлової - колодою карт з запитаннями, наприклад: чи відповідає це моїм цінностям / планам діяльності? Що тут треба прибрати / змінити / доповнити / посилити? Як я узнаю, що досяг результату, що іду в правильному напрямку? Якої зміни в мені, якої трансформації потребує саме ця мета / ситуація / проект тощо?

Метафора сходів у роботі з актуальними цілями (О. Угрин [26]).

Мета вправи: визначити власні пріоритетні сторони життя, усвідомити свою актуальну ціль, розкрити приховані ресурси в її досягненні.

1 етап - діагностичний.

«Колесо балансу життя» дозволяє визначити пріоритетні сторони життя, усвідомити та працювати 3 тими сферами, що утруднюють розвиток особистості.

Потрібно оцінити кожну сферу (духовність; здоров'я та спорт; гроші; кар'єра та бізнес; оточення і друзі; любов, сім'я, діти; саморозвиток; хобі та розваги, учасники можуть за бажанням змінити сфери на свої) за 10-ти бальною шкалою, де 0 - не задоволеність цією сферою чи відсутність її у вашому житті, 10 - максимальний іiі розвиток. Свою оцінку позначте крапкою всередині кожного сектора, після чого з'єднайте всі крапки разом. 


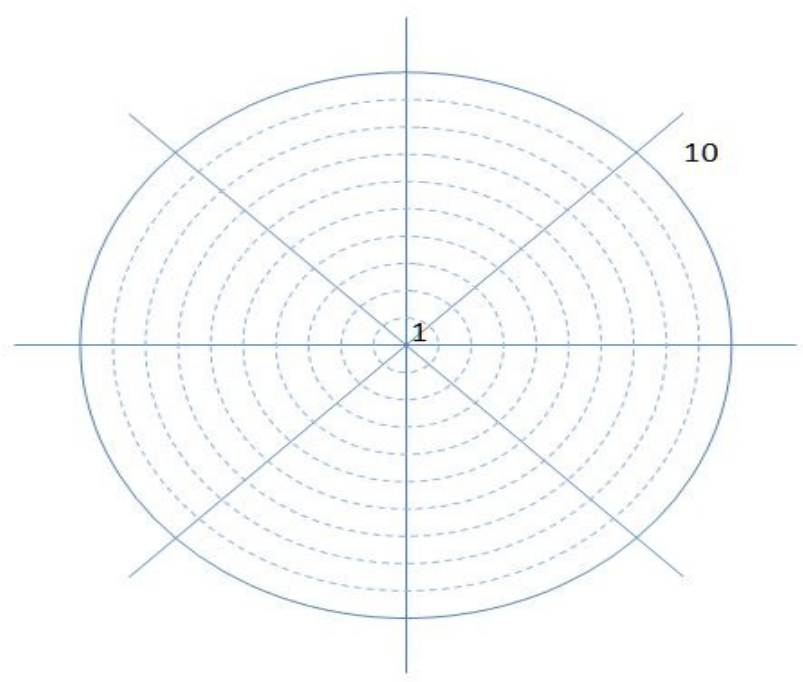

Чим більше фігура наближена до кола, тим більше людина всебічно гармонійна та реалізована. Ця техніка наочно демонструє ту сферу життя, на яку слід звернути увагу і дозволяє виокремити її актуальну ціль. Далі необхідно написати конкретну ціль, з якою працювати.

2 етап - візуалізація образу сходів із подальшим аналізом.

На аркуші паперу намалюйте сходи до своєї мети саме такі, які найкращим чином допоможуть її досягнути. У процесі аналізу учасник може надписувати сходинки, домальовувати, тощо.

Запитання для аналізу сходів:

1. Опишіть сходи. (Які вони? 3 якого матеріалу?).

2. Де знаходяться сходи? Що розташоване поряд із ними?

3. Хто їх створив?

4. Хто власник?

5. Яка їхня функція?

6. Куди вони ведуть?

7. Хто може ними користуватись?

8. Як би ви їх назвали?

9. Позначте себе, де ви зараз? Опишіть своє відчуття, ставлення до цього місця. Як ви себе почуваєтесь на цьому місці?

10. Позначте місце, де б ви хотіли стояти в майбутньому.

11. Уявіть собі, що ви досягли бажаного. Опишіть свій стан, відчуття.

12. Як швидко ви досягли мети?

13. Що потрібно зробити, щоб бути там, де ви хочете?

14. Хто вам може допомогти?

15. Що може зашкодити? 
16. Чи є хтось біля сходів? Хто вони? Що роблять?

17. Які ви маєте ресурси, щоб досягти бажаного?

18. Із чого слід почати?

Аналіз вправи можливо доповнити авторською розробкою Наталії Павлової - колодою карт з запитаннями, наприклад: чи відповідає це моїм цінностям / планам діяльності? Що тут треба прибрати / змінити / доповнити / посилити? Як я узнаю, що досяг результату, що іду в правильному напрямку? Якої зміни в мені, якої трансформації потребує саме ця мета / ситуація / проект тощо?

\section{6. ВИСНОВКИ ТА ПЕРСПЕКТИВИ ПОДАЛЬШИХ ДОСЛІДЖЕНЬ / CONCLUSIONS AND PROSPECTS FOR FURTHER RESEARCH}

П. Лушин [15] підкреслює важливість впровадження гіг-освіти відповідно до нової реальності і практиці VUCA-світу: постійного перевизначення цілей, форм і методів освітнього процесу. В умовах VUCAсвіту головним стає не зміст, який підлягає засвоєнню, а готовність толерувати невизначеність, жити в стані постійних трансформацій. П.Лушин [16] також описує людей 3 інтолерантним ставленням до визначеності як відносно пізнього типу розвитку особистості, який по суті $\epsilon$ внутрішньою проекцією VUCA-світу. Таким людям $\epsilon$ притаманним виходити за межі існуючих стереотипів, створювати нові поведінкові та смислові конструкти. Водночас люди з інтолерантним ставленням до визначеності часто страждають від нерозуміння себе і спричиняють навмисно чи ненавмисно страждання людям, інтолерантним до невизначеності.

Методики артрозвитку через усвідомлення своїх почуттів, емоцій, станів допомагають фахівцям подивитися на зміни 3 точки зору перспектив розвитку, що відкриваються, доводять ресурсність постійного навчання. Коли навички доводиться постійно оновлювати, щоб залишатися конкурентоспроможними, психологічна готовність до постійного навчання у дорослому віці, не зважаючи на професійні досягнення, які є, за допомогою навичок, які вже застарілі, стає необхідною умовою для успішної професійної діяльності. Таку готовність до постійного навчання також можна розглядати як профілактику психологічних травм під час проходження професійних криз.

У контексте проходження професійних криз особливу увагу слід приділити арт-коучингу. О. Вознесенська [9] визначає наступні сфери використання арткоучингу: консультування здорових людей щодо розширення їхніх досягнень, розвитку особистих здібностей, 
удосконалення взаємостосунків, розвитку команди, організації тощо. До функцій арткоуча належать запитання, які прояснюють цілі та спонукають клієнта рухатися в заданому ним самим напряму.

Перспективи подальших досліджень. Серед перспектив подальших досліджень можливо відмітити аналіз особливостей VUCA-світу та творчої, професійної самореалізації дорослої особистості в такому мінливому, непередбачуваному контексті. Особливу увагу заплановано приділити важливості недискримінаційних цінностей в якості орієнтира особистісного, творчого та професійного розвитку. Метафоричні асоціативні карти буде розглянуто в якості дієвого інструменту арткоучингу в освіті дорослих.

\section{7. СПИСОК ВИКОРИСТАНИХ ДЖЕРЕЛ / REFERENCES (TRANSLATED AND TRANSLITERATED)}

[1] П. І. Блозва, «Соціальний капітал як психологічний ресурс становлення політичної культури молоді»: дис. канд. наук. Київ, 2017, $211 \mathrm{c.}$

[2] I. О.Бондаревська, «Феномен довіри в економічних та міжетнічних відносинах (аналіз зарубіжних досліджень)», Актуальні проблеми психології: зб. наук. праць Інституту психології імені Г. С. Костюка НАПН України. Київ: Фенікс, Т. 11, вип. 12, с. 42-50, 2015.

[3] I. О. Бондаревська, В. О. Михайленко, «Психологічний аналіз соціального капіталу в спільнотах іммігрантів та біженців», Педагогіка і психологія: Вісник НАПН України. Київ: Педагогічна преса, № 2(91), с. 71-76, 2016.

[4] И. О.Бондаревская, «Гражданская идентичность личности в новостном медиа пространстве», Studia Universitatis Moldoviae. Seria: Pedagogie, Psihologie - Chisinau: State University of Moldova, № 9(119), c. 104-108, 2018.

[5] И. О. Бондаревская, В. А. Михайленко, «Психологический анализ доверия освещению проблем мигрантов новостными медиа», Науковий часопис НПУ ім. М. П. Драгоманова. Серія: Психологічні науки. Київ: Вид-во НПУ імені М. П. Драгоманова, № 7(52), с. 5-24, 2018.

[6] I. О. Бондаревська, В. О. Михайленко, «Довіра новинним медіа, національна ідентичність та громадянська активність опору серед підлітків», Проблеми сучасної психології: зб. наук. праць Запорізького нац. ун-ту та Інституту психології імені Г. С. Костюка НАПН України. Запоріжжя: ЗНУ, № 1(15), с. 16-22, 2019.

[7] И. О. Бондаревская, В. А. Михайленко, «Гражданская активность: роль социальных медиа», Проблеми сучасної психології: зб. наук. праць 
Кам'янець-Подільського нац. ун-ту та Інституту психології імені Г. С. Костюка НАПН України. Кам'янець-Подільський: Аксіома, Вип. 46, С. 40-58, 2019.

[8] О. І. Бондарчук, «Суб’єктивне благополуччя як індикатор успішного життєвого шляху керівників освітніх організацій», Теоретичні $i$ прикладні проблеми психології: зб. наук. праць Східноукр. нац. ун-ту ім. Володимира Даля. Сєвєродонецьк: Вид-во СНУ ім. В. Даля, Вип. 3(3), с. 37-46, 2018.

[9] О.Л. Вознесенська та ін., Енциклопедичний словник з арт-терапії. Київ, Україна: Видавець ФОП Назаренко, 2017, 312 с.

[10] О.В.Длугопольський, Ю. П. Івашук, «Розгул» корупції та рейдерства як фактор неефективності захисту прав власності», Научные труды ДонНТУ, № 2(44), с. 125-131, 2013.

[11] О. В. Длугопольський», Ю. П. Івашук, «Сучасні погляди на корупцію та мінімізацію її негативного впливу на економіку України», Економіка України, № 9, с. 13-24, 2012.

[12] М. Долинова, «Как «дневник каракулей» помогает разобраться в себе», Психологическая мастерская «Просто», 2017. [Электронный ресурс]. Доступно: http://dolinova.blog/archives/86.

[13] Л. Д. Лебедева, Ю. В. Никонорова, Н. А. Тараканова, Энциклопедия признаков и интерпретаций в проективном рисовании и арттерапии. Санкт-Петербург, Россия: Речь, 2006, 336 с.

[14] Г. В.Ложкін, В. В. Спасєнніков, В. Л. Комаровська, Економічна психологія. Київ, Україна: ВД «Професіонал», 2004, 304 с.

[15] П. В. Лушин, «Когда хаос и неопределённость внутри: VUCA-люди», Теория и практика психотерапии, № 3(11) с. 2-4, 2016.

[16] П. В.Лушин, «Гіг-освіта як альтернатива НУШ», Вісник психології $i$ соціальної педагогіки, Вип. 26, 2020. [Електронний ресурс]. Доступно: https://www.psyh.kiev.ua/\%d0\%97\%d0\%b1\%d1\%96\%d1\% 80\%d0\%bd\%d0\%b8\%d0\%ba \%d0\%bd\%d0\%b0\%d1\%83\%d0\%ba. \%d0 $\%$ bf $\%$ d $1 \% 80 \%$ d0\%b0\%d1\%86\%d1\%8c. \%d0\%92\%d0\%b8\%d0\%bf\%d1\%83\%d1\%81\%d0\%ba 26

[17] С. Д. Максименко, Л. М. Карамушка, О. В. Креденцер, Економічна психологія. Київ, Україна: Міленіум, 2004, 34 с.

[18] Медіапсихологія: на перетині інформаційного та освітнього просторів / Л. А. Найдьонової, Н.І.Череповської, Ред.; Національна академія педагогічних наук України, Інститут соціальної та політичної психології. Київ, Україна: Міленіум, 2014, 348 с. 
[19] О. Молчанова, Застосування ліній, каракулів та геометричних форм у процесі спонтанної творчості терапевтичного малювання. Київ, Україна, 2020, 78 с.

[20] Л. А. Найдьонова, Медіапсихологія: основи рефлексивного підходу; Національна академія педагогічних наук України, Інститут соціальної та політичної психології. Кіровоград, Україна: Імекс-ЛТД, 2015, 244 с.

[21] Ю. Н. Петрушенко, Н. Н. Костюченко, «Исследование влияния программ, предполагающих экономическую кооперацию, на социальный капитал местных сообществ», Наукові праці Донещького національного технічного ун-ту. Серія Економічна, Вип. 3(45), с. 167173, 2013.

[22] Практикум по гендерной психологии / И. С. Клёциной, Ред. СанктПетербург, Россия: Питер, 2002, 478 с.

[23] I. Семків, «Психометричні показники та адаптація методики Р. Стили "KPIKS" (Українська версія: опитувальник вимірювання індивідуального соціального капіталу (ОВІСК) адаптація І. Семків)», Гуманітарний вісник, № 37, с. 136-146, 2015.

[24] Соціальна психологія бідності / Т. І. Бєлавіна, В.О.Васютинський, В. Ю. Вінков та ін.; В.О. Васютинського, Ред.; Національна академія педагогічних наук України, Інститут соціальної та політичної психології. Київ, Україна: Міленіум, 2016, 294 с.

[25] М. Г.Ткалич, «Психолого-організаційні детермінанти самоактуалізації менеджерів комерційних організацій», дис. канд. наук. Київ, 2006, 266 c.

[26] О.Угрин, «Метафора сходів у роботі з актуальними цілями», на XVII Міжнародної міждисциплінарної наук-практ. конф. Простір арттерапії. Київ, 2020, с. 171-175.

[27] К. Фопель, Технология ведения тренинга. Теория и практика. Москва, Россия: Генезис, 2003, 368 с.

[28] I. Bondarevskaya, B. Krzywosz-Rynkiewicz, E. Bondar, «Young people's citizenship activity in times of war threat: Case of Ukraine», Citizenship Teaching and Learning - Intellect Limited, № 12(2), p. 189-206, 2017.

[29] C. Castelfranchi, R. Falcone, Trust Theory: A Socio-Cognitive and Computational Model. West Sussex: Wiley, 2010.

[30] J. T. Jost, P. Barbera, R. Bonneau, M. Langer, M. Metzger, J. Nagler, J. Sterling, J. A. Tucker, «How social media facilitates political protests: Information, motivation, and social networks», Advances in Political Psychology, № 39(1), p. 85-118, 2018. 
[31] E. Kirchler, E. Hoelzl, I. Wahl, «Enforced versus voluntary tax compliance: The "slippery slope" framework», Journal of Economic Psychology, № 29, p. 210-225, 2008.

[32] R. C. Mayer, J. H. Davis, F. D. Schoorman, «An integrative model of organizational trust», Academy of Management Review, № 20, p. 709-734, 1995.

[33] B. A. Misztal, Trust in modern societies. Cambridge: Polity Press, 1996.

[34] W.F.van Raaij, "Consumer confidence and trust in the economy», Economic psychology in modern world: collected papers; A. N. Lebedev, Eds. Moscow, Russia: Ekon-inform, 2012, p. 377-395.

A. M. Zalewska \& B. Krzywosz-Rynkiewicz, Psychologiczne portrety młodych obywateli. Warszawa: Wydawnictwo SWPS Academica, 2011.

\title{
CURRICULUM «PSYCHOLOGY OF ECONOMIC BEHAVIOR OF A SPECIALIST» WITH ART-DEVELOPMENT TECHNIQUES
}

\author{
Irina Bondarevskaya, \\ $\mathrm{PhD}$, Associate Professor, \\ Head of the Board in NGO «Center for Personal and Social Transformations», \\ Associate Professor of Department of Management Psychology \\ of the Central Institute of Postgraduate Education \\ SIHE «University of Educational Management», \\ Senior Researcher of Department of \\ Mass Communication Psychology and Media Education, \\ Institute for Social and Political Psychology, NAES of Ukraine. \\ Kyiv, Ukraine. \\ ORCID iD: https://orcid.org/0000-0002-7006-0979 \\ SCOPUS ID: 57196437901 \\ bondarevskaya@ua.fm \\ Viktoriya Mykhaylenko, \\ PhD, Associate Professor, \\ Associate Professor of Department of Socio-Humanity Preparation, \\ Odessa State Academy of Technical Regulation and Quality. \\ Odessa, Ukraine. \\ ORCID iD: https://orcid.org/0000-0003-2584-5571 \\ mykhaylenkova@ukr.net
}

Annotation. The article presents content and structure of curriculum «Psychology of economic behavior of a specialist». Special course contains complex of art-development techniques as techniques for actualization of person's potential in adult education. Special course was developed and implemented on Department of Management Psychology in Central Institute 
of Post-Graduate Education of University of Educational Management. As a result of training on the program of this special course specialists will acquire knowledge on peculiarities of trust in economic and interethnic relations; become aware of peculiarities of social capital functioning in different communities and role of citizenship activity in support of sustainable economic development; will be able to develop skills of prevention of corruption behavior which undermines economic trust and treats social capital functioning. Art-development techniques through awareness of feelings, emotions, states help specialists to see changes from the point of view of opening perspective for development, show resourcefulness of permanent learning. In conditions of permanent renewal of skills in order to remain competitive, psychological readiness for constant learning in adult age, despite professional achievements gained by outdated skills, becomes indispensable condition for successful professional activity. Such readiness for constant learning can be also considered as prophylaxis of psychological traumatization in professional crises passing. Actualization, development and realization of person's potential often occurs in the process of shifting from one professional sphere to another. Orientation on personal values in uncertain VUCA-world requires awareness of these values and goals as orientation in behavior strategy choice and actions in each concrete situation. We consider visual metaphor as inherent component of adult education due to activation of emotional and intellectual spheres in conditions of ambiguous and uncertain meanings.

Keywords: curriculum; adult education; art-development techniques; actualization of person's potential; VUCA-world; economic behavior. 


\title{
УЧЕБНАЯ ПРОГРАМА «ПСИХОЛОГИЯ ЭКОНОМИЧЕСКОГО ПОВЕДЕНИЯ СПЕЦИАЛИСТА» С МЕТОДИКАМИ АРТ-РАЗВИТИЯ
}

\author{
Бондаревская Ирина Олеговна, \\ кандидат психологических наук, доцент, \\ Глава Правления 00 «Центр личностных и социальных трансформаций», \\ доцент кафедры психологии управления \\ Центрального института последипломного образования \\ ГУВО «Университет менеджмента образования», \\ старший научный сотрудник лаборатории психологии \\ массовой коммуникации и медиа образования \\ Института социальной и политической психологии НАПН Украины. \\ Киев, Украина. \\ ORCID iD: https://orcid.org/0000-0002-7006-0979 \\ SCOPUS ID: 57196437901 \\ bondarevskaya@ua.fm
}

\section{Михайленко Виктория Александровна, кандидат психологических наук, доцент доцент кафедры социально-гуманитарной подготовки Одесской государственной академии технического регулирования и качества. ORCID iD: https://orcid.org/0000-0003-2584-5571 mykhaylenkova@ukr.net}

Аннотация. В статье представлены содержание и структура учебной программы «Психология экономического поведения специалиста». Спецкурс содержит комплекс методик арт-развития как методик актуализации потенциала личности специалиста в образовании взрослых. Спецкурс был разработан и внедрён на кафедре психологии управления Центрального института последипломного образования ГУВО «Университет менеджмента образования». В результате прохождения спецкурса специалисты получат знания об особенностях доверия в экономических и межэтнических отношениях; осознают особенности функционирования социального капитала в разных сообществах и роль гражданской активности в обеспечении устойчивого экономического развития; смогут развить умения и навыки предотвращения коррупционного поведения, которое подрывает экономическое доверие и несёт угрозу функционированию социального капитала. Методики арт-развития через осознание своих чувств, эмоций, состояний помогают специалистам посмотреть на изменения с точки зрения открывающихся перспектив развития, показывают ресурсность постоянного обучения. Когда навыки 
приходится постоянно обновлять, чтобы оставаться конкурентоспособными, психологическая готовность к постоянному обучению во взрослом возрасте, не смотря на уже имеющиеся профессиональные достижения при помощи устаревших навыков, становится необходимым условием для успешной профессиональной деятельности. Такую готовность к постоянному обучению также можно рассматривать в качестве профилактики психологических травм при прохождении профессиональных кризисов. Актуализация, развитие и реализация потенциала личности зачастую происходят в процессе перехода из одной профессиональной сферы в другую. Ориентация на свои ценности в неопределённом VUCA-мире требует осознания этих ценностей и целей в качестве ориентира при выборе стратегии поведения и вариантов поступков в каждой конкретной ситуации. Визуальная метафора рассматривается в качестве неотъемлемого компонента образования взрослых благодаря активизации эмоциональной и интеллектуальной сфер в условиях неопределённых смыслов.

Ключевые слова: учебная программа; образование взрослых; методики арт-развития; актуализация потенциала личности; VUCAмир; экономическое поведение.

\section{REFERENCES (TRANSLATED AND TRANSLITERATED)}

[1] P. I. Blozva, «Sotsialnyi kapital yak psykholohichnyi resurs stanovlennia politychnoi kultury molodi»: dys. kand. nauk. Kyiv, 2017, 211 s.

[2] I. O. Bondarevska, «Fenomen doviry v ekonomichnykh ta mizhetnichnykh vidnosynakh (analiz zarubizhnykh doslidzhen)», Aktualni problemy psykholohii: zb. nauk. prats Instytutu psykholohii imeni H. S. Kostiuka NAPN Ukrainy. Kyiv: Feniks, T. 11, vyp. 12, s. 42-50, 2015.

[3] I. O. Bondarevska, V. O. Mykhailenko, «Psykholohichnyi analiz sotsialnoho kapitalu V spilnotakh immihrantiv ta bizhentsiv», Pedahohika i psykholohiia: Visnyk NAPN Ukrainy. Kyiv: Pedahohichna presa, № 2(91), s. 71-76, 2016.

[4] I. O. Bondarevskaya, «Grazhdanskaya identichnost' lichnosti v novostnom media prostranstve», Studia Universitatis Moldoviae. Seria: Pedagogie, Psihologie - Chisinau: State University of Moldova, № 9(119), s. 104-108, 2018.

[5] I. O. Bondarevskaya, V. A. Mihajlenko, «Psihologicheskij analiz doveriya osveshcheniyu problem migrantov novostnymi media», Naukovyi 
chasopys NPU im. M. P. Drahomanova. Seriia: Psykholohichni nauky. Kyiv: Vyd-vo NPU imeni M. P. Drahomanova, № 7(52), s. 5-24, 2018.

[6] I. O. Bondarevska, V. O. Mykhailenko, «Dovira novynnym media, natsionalna identychnist ta hromadianska aktyvnist oporu sered pidlitkiv», Problemy suchasnoi psykholohii: zb. nauk. prats Zaporizkoho nats. un-tu ta Instytutu psykholohii imeni H. S. Kostiuka NAPN Ukrainy. Zaporizhzhia: ZNU, № 1(15), s. 16-22, 2019.

[7] I. O. Bondarevskaya, V. A. Mihajlenko, «Grazhdanskaya aktivnost': rol' social'nyh media», Problemy suchasnoi psykholohii: zb. nauk. prats Kamianets-Podilskoho nats. un-tu ta Instytutu psykholohii imeni H.S. Kostiuka NAPN Ukrainy. Kamianets-Podilskyi: Aksioma, Vyp. 46, s. $40-58,2019$.

[8] O. I. Bondarchuk, «Subiektyvne blahopoluchchia yak indykator uspishnoho zhyttievoho shliakhu kerivnykiv osvitnikh orhanizatsii», Teoretychni i prykladni problemy psykholohii: zb. nauk. prats Skhidnoukr. nats. un-tu im. Volodymyra Dalia. Sievierodonetsk: Vyd-vo SNU im. V. Dalia, Vyp. 3(3), s. 37-46, 2018.

[9] O. L. Voznesenska ta in., Entsyklopedychnyi slovnyk z art-terapii. Kyiv, Ukraina: Vydavets FOP Nazarenko, 2017, 312 s.

[10] O. V. Dluhopolskyi, Yu. P. Ivashuk, «Rozghul» koruptsii ta reiderstva yak faktor neefektyvnosti zakhystu prav vlasnosti», Nauchnыe trudы DonNTU, № 2(44), s. 125-131, 2013.

[11] O.V. Dluhopolskyi, Yu. P. Ivashuk, «Suchasni pohliady na koruptsiiu ta minimizatsiiu yii nehatyvnoho vplyvu na ekonomiku Ukrainy», Ekonomika Ukrainy, № 9, s. 13-24, 2012.

[12] M. Dolinova, «Kak «dnevnik karakulej» pomogaet razobrat'sya v sebe», Psihologicheskaya masterskaya «Prosto», 2017. [Elektronnyj resurs]. Dostupno: http://dolinova.blog/archives/86.

[13] L. D. Lebedeva, YU. V. Nikonorova, N. A. Tarakanova, Enciklopediya priznakov i interpretacij $\mathrm{v}$ proektivnom risovanii i art-terapii. SanktPeterburg, Rossiya: Rech', 2006, 336 s.

[14] H. V. Lozhkin, V. V. Spasiennikov, V. L. Komarovska, Ekonomichna psykholohiia. Kyiv, Ukraina: VD «Profesional», 2004, 304 s.

[15] P. V. Lushin, «Kogda haos i neopredelyonnost' vnutri: VUCA-lyudi», Teoriya i praktika psihoterapii, № 3(11) s. 2-4, 2016.

[16] P. V. Lushyn, «Hih-osvita yak alternatyva NUSh», Visnyk psykholohii i sotsialnoi pedahohiky, Vyp. 26, 2020. [Elektronnyi resurs]. Dostupno: https://www.psyh.kiev.ua/\%d0\%97\%d0\%b1\%d1\%96\%d1\%80\%d0\%bd 
\%d0\%b8\%d0\%ba \%d0\%bd\%d0\%b0\%d1\%83\%d0\%ba. \%d0\%bf\%d1\%80\%d0\%b0 \%d1\%86\%d1\%8c. - \%d0\%92\%d0\%b8\%d0\%bf\%d1\%83\%d1\%81\%d0\%ba 26

[17] S. D. Maksymenko, L. M. Karamushka, O. V. Kredentser, Ekonomichna psykholohiia. Kyiv, Ukraina: Milenium, 2004, 34 s.

[18] Mediapsykholohiia: na peretyni informatsiinoho ta osvitnoho prostoriv / L. A. Naidonovoi, N. I. Cherepovskoi, Red.; Natsionalna akademiia pedahohichnykh nauk Ukrainy, Instytut sotsialnoi ta politychnoi psykholohii. Kyiv, Ukraina: Milenium, 2014, 348 s.

[19] O. Molchanova, Zastosuvannia linii, karakuliv ta heometrychnykh form u protsesi spontannoi tvorchosti terapevtychnoho maliuvannia. Kyiv, Ukraina, 2020, $78 \mathrm{~s}$.

[20] L. A. Naidonova, Mediapsykholohiia: osnovy refleksyvnoho pidkhodu; Natsionalna akademiia pedahohichnykh nauk Ukrainy, Instytut sotsialnoi ta politychnoi psykholohii. Kirovohrad, Ukraina: Imeks-LTD, 2015, 244 s.

[21] YU. N. Petrushenko, N. N. Kostyuchenko, «Issledovanie vliyaniya programm, predpolagayushchih ekonomicheskuyu kooperaciyu, na social'nyj kapital mestnyh soobshchestv», Naukovi pratsi Donetskoho natsionalnoho tekhnichnoho un-tu. Seriia Ekonomichna, Vyp. 3(45), s. 167-173, 2013.

[22] Praktikum po gendernoj psihologii / I. S. Klyocinoj, Red. Sankt-Peterburg, Rossiya: Piter, 2002, 478 s.

[23] I. Semkiv, «Psykhometrychni pokaznyky ta adaptatsiia metodyky R. Styly "KPIKS" (Ukrainska versiia: opytuvalnyk vymiriuvannia indyvidualnoho sotsialnoho kapitalu (OVISK) adaptatsiia I. Semkiv)», Humanitarnyi visnyk, № 37, s. 136-146, 2015.

[24] Sotsialna psykholohiia bidnosti / T. I. Bielavina, V. O. Vasiutynskyi, V.Yu. Vinkov ta in.; V. O. Vasiutynskoho, Red.; Natsionalna akademiia pedahohichnykh nauk Ukrainy, Instytut sotsialnoi ta politychnoi psykholohii. Kyiv, Ukraina: Milenium, 2016, 294 s.

[25] M. H. Tkalych, «Psykholoho-orhanizatsiini determinanty samoaktualizatsii menedzheriv komertsiinykh orhanizatsii», dys. kand. nauk. Kyiv, 2006, $266 \mathrm{~s}$.

[26] 0. Uhryn, «Metafora skhodiv u roboti $\mathrm{z}$ aktualnymy tsiliamy», na XVII Mizhnarodnoi mizhdystsyplinarnoi nauk.-prakt. konf. Prostir artterapii. Kyiv, 2020, s. 171-175.

[27] K. Fopel', Tekhnologiya vedeniya treninga. Teoriya i praktika. Moskva, Rossiya: Genezis, 2003, 368 s. 
[28] I. Bondarevskaya, B. Krzywosz-Rynkiewicz, E. Bondar, «Young people's citizenship activity in times of war threat: Case of Ukraine», Citizenship Teaching and Learning - Intellect Limited, № 12(2), p. 189-206, 2017.

[29] C. Castelfranchi, R.Falcone, Trust Theory: A Socio-Cognitive and Computational Model. West Sussex: Wiley, 2010.

[30] J. T. Jost, P. Barbera, R. Bonneau, M. Langer, M. Metzger, J. Nagler, J.Sterling, J. A. Tucker, «How social media facilitates political protests: Information, motivation, and social networks», Advances in Political Psychology, № 39(1), p. 85-118, 2018.

[31] E. Kirchler, E. Hoelzl, I. Wahl, «Enforced versus voluntary tax compliance: The "slippery slope" framework», Journal of Economic Psychology, № 29, p. 210-225, 2008.

[32] R. C. Mayer, J. H. Davis, F. D. Schoorman, «An integrative model of organizational trust», Academy of Management Review, № 20, p. 709-734, 1995.

[33] B. A. Misztal, Trust in modern societies. Cambridge: Polity Press, 1996.

[34] W.F.van Raaij, «Consumer confidence and trust in the economy», Economic psychology in modern world: collected papers; A. N. Lebedev, Eds. Moscow, Russia: Ekon-inform, 2012, p. 377-395.

[35] A. M. Zalewska \& B. Krzywosz-Rynkiewicz, Psychologiczne portrety młodych obywateli. Warszawa: Wydawnictwo SWPS Academica, 2011. 